\title{
Phenotypic Characterization for Identification, Conservation and Sustainable Utilization of Boset and Minjar Shenkora Goats of Ethiopia
}

\author{
Tesfalem Aseged ${ }^{1, a, *}$, Abraham Assefa ${ }^{1, b}$, Abebe Hailu ${ }^{1, c}$, Tesfaye Getachew ${ }^{2, d}$, \\ Manaye Misganaw ${ }^{1, \mathrm{e}}$, Seble Sinke ${ }^{1, \mathrm{f}}$, Fasil Getachew ${ }^{3, g}$, Solomon Abegaz ${ }^{4, \mathrm{~h}}$ \\ ${ }^{1}$ Animal Biodiversity Directorate, Ethiopian Biodiversity Institute, P.O. Box 30726, Addis Ababa, Ethiopia \\ ${ }^{2}$ International Center for Agricultural Research in the Dry Areas, Addis Ababa, Ethiopia \\ ${ }^{3}$ International Livestock Research Institute, Addis Ababa, Ethiopia \\ ${ }^{4}$ Ethiopian Institute of Agricultural Research, Debre Zeit, Ethiopia \\ *Corresponding author
}

A R T I C L E I N F O

\section{A B S T R A C T}

Research Article

Received : 02/06/2021

Accepted : 05/10/2021

Keywords:

Goat breed

Qualitative traits

Quantitative traits

Boset

Minjar Shenkora

\begin{abstract}
This study was conducted on a total of 776 goats (part of Central highland goat breeds of Ethiopia) 306 from Boset district of Oromia region and 470 were from Minjar Shenkora district of Amhara region. A format developed by using food and agriculture organization discerption list was used for recording of morphological traits, bodyweight and linear body measurements. Both qualitative and quantitative traits were recorded from randomly sampled mature goats and the data were analyzed using SAS software. The goat type in the study area was characterized by a higher proportion of plain coat color patterns (62.5). Ingeneral, the majority $(98.4 \%)$ of the studied goats were horned and characterized by backward orientation $(67 \%)$ with a straight shape $(49.3 \%)$. They presented a concave facial profile $(73.8 \%)$, slop up toward the rump back profile $(66.2 \%)$, no wattle $(99.6 \%)$, no toggle $(90.7 \%)$, no ruff $(85.9 \%)$ and no beard $(57.3 \%)$. The location had a significant effect on body weight and some other linear body measurements. Traits like body length, rump length, horn length, head length, head width and shin circumference were significantly higher in Boset district. In contrast, rump width and cannon bone length were significantly lower. The mean body weight of male goats in Boset and Minjar Shenkora district were $30.5 \pm 1.05 \mathrm{~kg}$ with a range of 16 to 47 and $27.5 \pm 0.56$ with a range of 13 to 57 , respectively. While for female counterpart mean body weights $(\mathrm{kg})$ were $28.4 \pm 0.35$ with a range of 17 to 45 for Boset and $27.5 \pm 0.33$ with a range 15 to 57 for Minjar Shenkora district. Heart girth had the highest correlation with body weight in both sexes and shoulder width in Boset male goats. The wider variation in most quantitative measurement traits would open an opportunity for further improvement, conservation and utilization work.
\end{abstract}

\footnotetext{
a@tesfalemaseged@gmail.com
c@abebehailu3@gmail.com
'- manaye9@gmail.com
9- fasilgetachew7@gmail.com
}
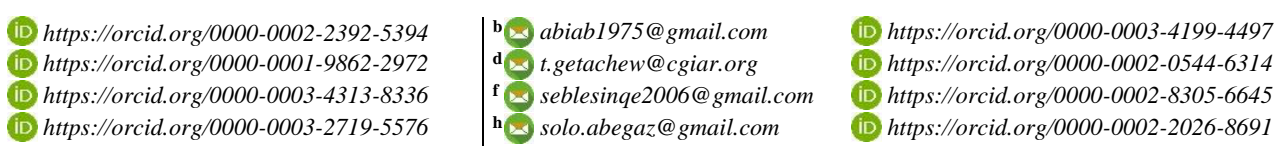

This work is licensed under Creative Commons Attribution 4.0 International License

\section{Introduction}

The presence of diverse agro-ecologies and being the historical route of the entry point of domestic livestock from Asia to Africa lead Ethiopia to be a home for large and diverse livestock resources. The diversified genetic resource is vital for the present and future livelihoods in the development of a sustainable animal production system, in the meeting of unpredictable future demand, climate change and more virulent disease pathogens,

Worldwide the number of goat breeds reached 570 among them 89 are in Africa (Galal, 2005), and within it, 8 breeds with 32.74 million heads are found in Ethiopia (CSA, 2018; EBI, 2014). However, to the opposite of its large size and existed diversity, the traditional management system and lack of intensive improvement works contribute to the low productivity of Ethiopian goats
(Gatew et al., 2015). Moreover, aggressive expansion of agricultural mechanization, new market demand and indiscriminate crossbreeding is a threat to the genetic resources of indigenous breeds (Mahmoudi et al., 2010). Therefore, sustainable genetic improvement works on indigenous breeds are important to revert the existing challenges. Furthermore, their adaptation to harsh climatic conditions, disease tolerance capacity (Khargharia et al., 2015) survival and reproduction ability in harsh environmental conditions and on poor quality fibrous feeds (Muluneh et al., 2016) pursues due attention.

Lack of information hinders decision-making concerning what to conserve, develop, and how to best use limited funds available for conservation, improvement and sustainable utilization (FAO, 2007). It is a well-known fact 
that in the absence of baseline characterization work, the breed and its unique characteristic may decrease before their value is fully understood, exploited, or conserved. Therefore, the knowledge of the existing genetic variability is the first step to conservation, improvement and sustainable utilize the resource (Ia et al., 2002). It is essential to characterize a breed for its conservation (Mahmoudi et al., 2010). Besides, phenotypic characteristics are important in breed identification and classification (Khargharia et al., 2015). However, in Ethiopia, the goat characterization in various forms has not been exhaustively undertaken (Dereje, 2015). Therefore, the objective of this study is to provide baseline information for in-situ conservation, improvement and sustainability of Boset and Minjar Shenkora indigenous goat populations of Ethiopia which is a part of Central highland goat breeds of the country.

\section{Materials and Methods}

\section{Study Areas}

The study was conducted in two bordering districts of Minjar Shenkora and Boset in Amhara and Oromia National Regional States respectively (Fig 1). There wasn't any goat passing between the adjoint districts. However, browsing land owned in Boset district were slightly higher than the adjacent district (Minjar Shenkora, Tesfalem et al., 2021).

Boset is located in the east of the capital city of Ethiopia, at about $100 \mathrm{~km}$, with north latitude and east longitude of $8^{\circ} 24^{\prime}-8^{\circ} 51^{\prime}$ and $39^{\circ} 16^{\prime}-39^{\circ} 50^{\prime}$ respectively. It has an altitude of 1500 m.a.s.l. with annual rainfalls and temperature ranged from 400 to $800 \mathrm{~mm}$ and 13.60 to $27.7^{\circ} \mathrm{C}$, respectively. Weinadega (midlands) and Kola (low lands) are the two major agro-climatic zones of the district.

Minjar Shenkora is located in the east of the capital city of Ethiopia, at about $135 \mathrm{~km}$, with north latitude and east longitude of $90^{\circ} 6^{\prime}-90^{\circ} 5^{\prime}$ and $39^{\circ} 46^{\prime}-39^{\circ} 26^{\prime}$ respectively. It has an altitude of 1900 m.a.s.l. with annual rainfalls and temperature ranged from 162.8 to $1028 \mathrm{~mm}$ and 7.3 to $27.7^{\circ} \mathrm{C}$, respectively. The district falls within three major agro-climatic zones, Dega (high lands), Weinadega (midlands) and Kola (low lands).

\section{Method of Data Collection}

Through discussing with agricultural development agents and considering goat population and road accessibility, representative districts and six representative kebeles (the smallest administrative units in Ethiopia next to district, it might consist more than 15 villages which comprising about 500 households or around 4000 persons) within each district were purposely selected. To identify the distinguishing features of the goat population (as goats in Ethiopia are not specialized and played multi-purpose role) both qualitative and quantitative body measurement records were taken on a total of 776 randomly selected mature goats. 470 heads were from Minjar Shenkora (301 females and 129 males and 40 castrated) and 306 heads from Boset (270 females and 36 males).

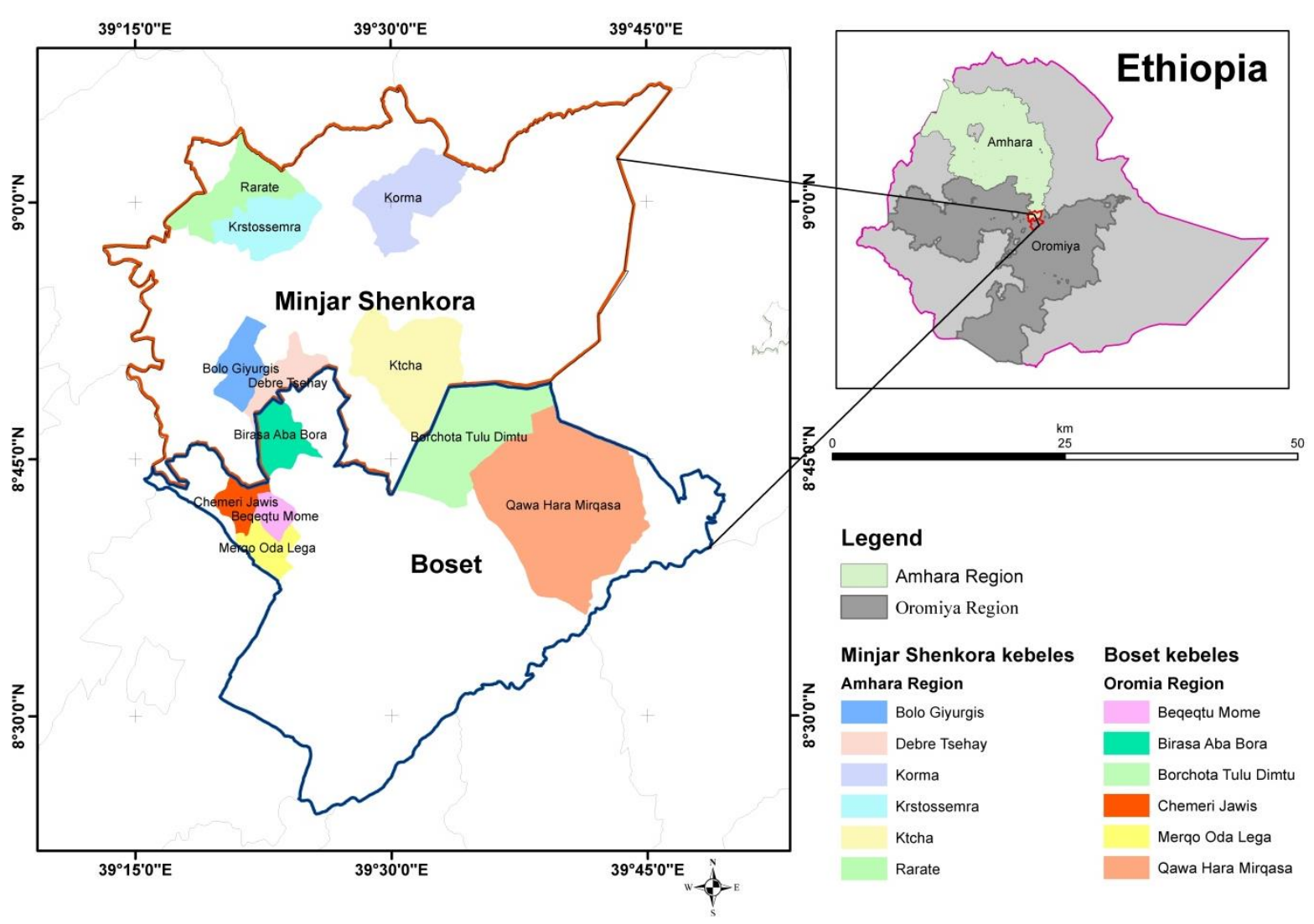

Figure1. Map of the Study Area (source: Tesfalem et al, 2021) 
Qualitative traits such as sex, coat color pattern, coat color type, body skin color, horn shape; horn and ear orientation; facial, rump and back profile; presence or absence of horn, wattles, toggle, beard and ruff were recorded through visual observation and by using breed morphological characteristics descriptor list of FAO (2012). Quantitative body measurement records taken for both sexes included body weight (BW), body length (BL), height at wither (HW), heart girth $(\mathrm{Hg})$, shoulder-width (SW), chest depth (ChD) and rump width (RW), rump length (RL), head length (HeL), head width (HeW), Horn Length (HL), Ear Length (EL), cannon bone length (CL) and shine circumference (ShC). Testicular circumference (TC) was also measured for males. Measurements were taken with a measuring tape while body weight was recorded using a suspended weighing scale by hanging up. The methods used for the measurements are as described by FAO (2012). All measurements were taken with goats standing steadily and in the morning before the animals left for watering and browsing.

\section{Statistical Analyses Techniques}

Qualitative and Quantitative body measurement data were analyzed by using SAS software; PROC FREQ, GLM and PROC REGS (SAS version 9.2, 2008). To assess the significance of categorical variables chi-square test was employed. For separate sex, districts were fitted as fixed effects while linear body measurements were fitted as dependent variables. The effect of the district was expressed as Least Square Means (LSM) \pm SE. The following model was used to analyze body weight and other linear body measurements for each sex.

$$
\mathrm{Yij}=\mu+\mathrm{Bi}+\varepsilon \mathrm{ij}
$$

Where:

Yij = Observed quantitative measurement of trait of interest

$\mu \quad=$ Overall mean

$\mathrm{Bi}=$ The effect of district $(\mathrm{i}=$ Boset, Minjar Shenkora)

cij = Random error associated with quantitative body measurements

Pearson's correlation coefficients were estimated among body weight and linear body measurements for each sex. To predict live bodyweight from other linear body measurements stepwise regression procedures were used. Bodyweight was estimated from other leaner body measurements for separate sex as follows:

$$
\mathrm{Y}=\beta 0+\beta 1 \mathrm{X} 1+\beta 2 \mathrm{X} 2+\ldots \beta \mathrm{nXn}+\mathrm{ej}
$$

Where:

$\mathrm{Y}=$ the response variable (bodyweight)

$\beta 0=$ the intercept

$\mathrm{X} 1 \ldots \mathrm{Xn}$ were the explanatory variables like body length, heart girth and horn length) $\mathrm{Xn}$

$\beta 1 \ldots \beta n$ are regression coefficients of the variables $X 1 \ldots$

ej $=$ random error

\section{Results and Discussion}

\section{Qualitative traits of the sample population}

Except for coat color pattern, presence of horn, wattle and bread, there was an association $(\mathrm{P}<0.05)$ between most qualitative variables and location (Table 1). The most frequent observed coat color patterns in the study area were plain $(62.5 \%)$ and patchy $(35.4 \%)$ with white and light red dominating color type. This may be attributed to the breed characteristics itself or the owner's preference for light coat color as it is important for the adaptation of the hot environment, so the animal can perform easily in the lowland (Hensen 1990). Moreover, shiny colored animals can be seen easily in the deep forest so the keeper can easily trace out the animal. Thus, any breeding program that would be designed in the area should consider the existed situations. However, from the conservation point of view and for sustained improvement work, due attention should be taken for animals with low observed traits. The coat color pattern in this study is in line with the report of Dereje (2015) and Hagos et al. (2016) for Begait goat of western Tigray. About $98.4 \%$ of the sampled goats were horned with straight dominating horn shape in Boset district, while curved in Minjar Shenkora. This may be attributed to socio-cultural and practical importance, as horned goats are expected to fight against predators. The finding is in line with goat types of west Gojam Zone (Muluneh et al., 2016). The dominant horn and ear orientation of the sampled goat in the studied area were backward (67\%) and semi pendulous $(84.8 \%)$, respectively. The observation is similar to the report of Alemu (2015) for Abergelle goats. The majority of the goat in the study area presented concave facial profile $(73.8 \%)$, slop up toward the rump back profile $(66.2 \%)$, no wattle $(99.6 \%)$, no toggle $(90.7 \%)$, no ruff $(85.9 \%)$ and no beard $(57.3 \%)$. This might be attributed to breed characters and/or the interest of the producer. The finding is similar to Hagan et al. (2012) for indigenous goats of Ghana. However higher proportions of Central Highland goats had beards and wattle (Zergaw et al., 2016; Muluneh et al., 2016).

\section{Quantitative traits of the sampled goat population \\ Body measurement variation in male goats}

The district had a significant effect $(\mathrm{P}<0.05)$ on body weight and most linear body measurements (LBMs) of male goat except heart girth, height at wither, shoulder width and ear length (Table 2). Most measurement traits like body weight, body length, rump length, horn length, head length, head width, shin circumference and testicular circumference were significantly $(\mathrm{P}<0.05)$ higher in Boset district. In contrast, chest depth, rump width and cannon bone length were significantly $(\mathrm{P}<0.05)$ lower. The difference might be due to differences in the management system, genetic by environment interaction, the breed characteristic itself, or the presence of strains within the breed. The mean body weights $(\mathrm{kg})$ were $30.5 \pm 1.05$ with a range of 16 to 47 (the result is not presented here), and $27.5 \pm 0.56$ with a range of 13 to 57 for Boset and Minjar Shenkora district respectively. This wide variation might be attributed to lack of a systematic selection program in the area that would help for setting up selection programs. The existed variation is an opportunity for sustainable 
improvement, conservation and utilization work that would be designed in the area. The average body weight reported in this study is similar to Short-eared Somali (27.8) and Central Highland goat (30.1) but lower than Western goat (around $33 \mathrm{~kg}$ ) (ESGPIP, 2009). The overall trait-based coefficient of variation (CV) was fluctuated from 7.49 to 32.04 for height at wither and horn length, respectively. The population effect $\left(\mathrm{R}^{2}\right)$ ranged from 0.00 for shoulder width and height at wither to 0.58 for cannon bone length.
Traits with low $\mathrm{R}^{2}$ with the correspondence high $\mathrm{CV}$ in the present study show the heterogeneity is within the population otherwise between the populations. Thus, varying the overall population effect (R2) in this study is attributed to both population and individual differences. The result is in line with the report of Alemu (2015), Dereje, (2015) and Hagos (2016) for Abergelle and Central highland goat breeds, indigenous cattle in Oromia region and Begait goat in western Tigray, respectively.

Table 1. Summary of qualitative variables of sampled goat in the two districts

\begin{tabular}{|c|c|c|c|c|c|c|}
\hline \multirow[b]{2}{*}{ Variable } & \multirow[b]{2}{*}{ Class level } & \multicolumn{2}{|c|}{ Female } & \multicolumn{2}{|r|}{ Male } & \multirow{2}{*}{$\begin{array}{l}\text { Total } \\
\text { N }(\%)\end{array}$} \\
\hline & & $\begin{array}{l}\text { Boset } \\
\mathrm{N}(\%) \\
\end{array}$ & $\begin{array}{c}\text { Minjar Shekora } \\
\mathrm{N}(\%)\end{array}$ & $\begin{array}{l}\text { Boset } \\
\mathrm{N}(\%)\end{array}$ & $\begin{array}{c}\text { Minjar Shenkora } \\
\mathrm{N}(\%)\end{array}$ & \\
\hline \multirow{4}{*}{ Coat colour pattern } & Plain & $228(84.4)$ & $152(50.3)$ & $20(55.6)$ & $85(50.6)$ & $485(62.5)$ \\
\hline & Patchy & $32(11.9)$ & $150(49.7)$ & $16(44.4)$ & $77(45.8)$ & $275(35.4)$ \\
\hline & Spotty & $10(3.7)$ & $\mathrm{Na}$ & $\mathrm{Na}$ & $6(3.6)$ & $16(2.1)$ \\
\hline & $\mathrm{X}^{2}(\mathrm{P})$ & & & & & $7.25(0.298)$ \\
\hline \multirow{4}{*}{ Horn } & Present & $265(98.5)$ & 297(98.7) & $34(94.4)$ & $165(98.8)$ & $763(98.4)$ \\
\hline & Absent & $4(1.5)$ & $4(1.3)$ & $2(5.6)$ & $2(1.2)$ & $12(1.6)$ \\
\hline & $\mathrm{X}^{2}(\mathrm{P})$ & \multicolumn{2}{|c|}{$0.03(0.0873)$} & \multicolumn{2}{|c|}{$2.91(0.88)$} & $0.57(0.45)$ \\
\hline & Scurs & $11(4.1)$ & $18(6.1)$ & $1(2.9)$ & $5(3.0)$ & $35(4.6)$ \\
\hline \multirow{4}{*}{ Horn shape } & Straight & $170(63.2)$ & 132(44.7) & $23(67.6)$ & $52(31.3)$ & $377(49.3)$ \\
\hline & Curved & $78(29.0)$ & $140(47.5)$ & $8(23.5)$ & $94(56.6)$ & 320 (41.9) \\
\hline & Spiral & $10(3.7 \%)$ & $5(1.7)$ & $29(5.9)$ & $15(9.0)$ & $32(4.2)$ \\
\hline & $\mathrm{X}^{2}(\mathrm{P})$ & \multicolumn{2}{|c|}{$24.63(0.000)$} & \multicolumn{2}{|c|}{$16.32(0.001)$} & $43.30(0.000)$ \\
\hline \multirow{4}{*}{ Horn orientation } & Obliquely & $5(1.9)$ & $31(10.5)$ & $0(0)$ & $4(2.4)$ & $40(5.2)$ \\
\hline & Upward & $100(37.3)$ & $73(24.7)$ & $11(32.4)$ & $28(16.8)$ & $212(27.7)$ \\
\hline & Backward & $163(60.8)$ & $191(64.7)$ & $23(67.6)$ & $135(80.8)$ & $512(67.0)$ \\
\hline & $\mathrm{X}^{2}(\mathrm{P})$ & \multicolumn{2}{|c|}{$23.97(0.000)$} & \multicolumn{2}{|c|}{$4.98(0.083)$} & $29.02(0.000)$ \\
\hline \multirow{5}{*}{ Ear orientation } & Erect & $11(4.1)$ & $\mathrm{Na}$ & $1(2.8)$ & $\mathrm{Na}$ & $12(1.6)$ \\
\hline & Semi pendulous & $183(67.8)$ & 288(96.0) & $25(69.4)$ & $160(95.2)$ & $656(84.8)$ \\
\hline & Pendulous & $5(1.9)$ & $1(0.3)$ & $2(5.6)$ & $2(1.2)$ & $10(1.3)$ \\
\hline & Carried horizontally & $71(26.3)$ & $11(3.7)$ & $8(22.2)$ & $6(3.6)$ & $96(12.4)$ \\
\hline & $\mathrm{X}^{2}(\mathrm{P})$ & \multicolumn{2}{|c|}{$29.62(0.000)$} & \multicolumn{2}{|c|}{$24.75(0.000)$} & $112.47(0.021)$ \\
\hline \multirow{3}{*}{ Facial profile } & Straight & $123(45.6)$ & $53(17.6)$ & $12(33.3)$ & $15(8.9)$ & $203(26.2)$ \\
\hline & Concave & $147(54.4)$ & $248(82.4)$ & $24(66.7)$ & 153(91.1) & $572(73.8)$ \\
\hline & $\mathrm{X}^{2}(\mathrm{P})$ & \multicolumn{2}{|c|}{$52.14(0.000)$} & \multicolumn{2}{|c|}{$15.38(0.000)$} & $84.03(0.000)$ \\
\hline \multirow{4}{*}{ Back profile } & Straight & $130(48.1)$ & $70(23.3)$ & $15(41.7)$ & $46(27.4)$ & $261(33.7)$ \\
\hline & Slop to rump & $139(51.5)$ & $231(76.7)$ & $21(58.3)$ & $122(72.6)$ & $513(66.2)$ \\
\hline & Slop to withers & $1(0.4)$ & $\mathrm{Na}$ & $0(0.0)$ & $\mathrm{Na}$ & $1(0.1)$ \\
\hline & $\mathrm{X}^{2}(\mathrm{P})$ & \multicolumn{2}{|c|}{$40.31(0.000)$} & & $89(0.89)$ & $44.52(0.000)$ \\
\hline & Flat & $142(52.6)$ & 144(47.80) & $15(41.7)$ & $59(35.1)$ & $360(46.5)$ \\
\hline & Sloping & $85(31.5)$ & $137(45.5)$ & $19(52.8)$ & 107(63.70) & $348(44.9)$ \\
\hline Rump profile & Roofy & $43(15.9)$ & $20(6.6)$ & $2(5.6)$ & $2(1.20$ & $67(8.6)$ \\
\hline & $\mathrm{X}^{2}(\mathrm{P})$ & 18.9 & $6(0.000)$ & & $30(0.149)$ & $37.47(0.000)$ \\
\hline & Present & $1(0.4)$ & $0(0.0)$ & $0(0.0)$ & $2(1.2)$ & $3(0.4)$ \\
\hline Wattle & Absent & $269(99.6)$ & $301(100.0)$ & $36(100.0)$ & $166(98.8)$ & 772(99.6) \\
\hline & $\mathrm{X}^{2}(\mathrm{P})$ & 1.1 & $2(0.291)$ & & $3(0.511)$ & $0.48(0.827)$ \\
\hline & Present & $37(13.9)$ & $15(5.0)$ & $4(11.1)$ & $16(9.5)$ & $72(9.3)$ \\
\hline Toggle & Absent & $230(86.1)$ & $286(95.0)$ & $32(88.90$ & $152(90.5)$ & 703(90.7) \\
\hline & $\mathrm{X}^{2}(\mathrm{P})$ & 13.0 & $8(0.000)$ & & $34(0.771)$ & $10.13(0.001)$ \\
\hline & Present & $83(30.7)$ & $79(26.2)$ & $31(86.1)$ & $138(82.1)$ & $331(42.7)$ \\
\hline Beard & Absent & $187(69.3)$ & $222(73.8)$ & $5(13.9)$ & $30(17.9)$ & $444(57.3)$ \\
\hline & $\mathrm{X} 2(\mathrm{P})$ & 1.4 & $2(0.234)$ & & $28(0.567)$ & $6.15(0.43)$ \\
\hline & Present & $3(1.1)$ & $5(1.7)$ & $31(86.1)$ & $70(41.7)$ & $109(14.1)$ \\
\hline Ruff & Absent & 267(98.9) & $296(98.3)$ & $5(13.9)$ & $98(58.3)$ & 666(85.9) \\
\hline & $\mathrm{X} 2(\mathrm{P})$ & 0.31 & $2(0.577)$ & 23. & $43(0.000)$ & $3.65(0.056)$ \\
\hline
\end{tabular}

$\mathrm{N}=$ number of observations, $\mathrm{Na}=$ not available 
Table 2. Quantitative body measurements of male goats ( $\mathrm{LSM} \pm \mathrm{SE}$ ) in the studied districts

\begin{tabular}{|c|c|c|c|c|c|c|}
\hline \multirow{2}{*}{ Traits } & \multirow{2}{*}{ Overall } & \multirow{2}{*}{$\mathrm{CV}$} & \multirow{2}{*}{$\mathrm{R}^{2}$} & \multicolumn{2}{|c|}{ Districts } & \multirow{2}{*}{$\mathrm{P}$-value } \\
\hline & & & & Boset & MinjarShenkora & \\
\hline Body length & $59.1 \pm 0.44$ & 8.00 & 0.09 & $60.9 \pm 0.77$ & $57.3 \pm 0.41$ & $<.0001$ \\
\hline Bodyweight & $29.0 \pm 0.60$ & 22.44 & 0.04 & $30.5 \pm 1.05$ & $27.5 \pm 0.56$ & 0.0126 \\
\hline Heart girth & $70.7 \pm 0.60$ & 8.00 & 0.02 & $71.6 \pm 0.94$ & $70.6 \pm 0.50$ & 0.0942 \\
\hline Height at wither & $64.8 \pm 0.46$ & 7.49 & 0.00 & $65.1 \pm 0.81$ & $64.6 \pm 0.43$ & 0.569 \\
\hline Chest depth & $30.1 \pm 0.23$ & 8.10 & 0.07 & $29.3 \pm 0.41$ & $31.0 \pm 0.22$ & 0.0004 \\
\hline Shoulder width & $14.7 \pm 0.16$ & 11.44 & 0.00 & $14.8 \pm 0.28$ & $14.9 \pm 0.15$ & 0.6206 \\
\hline Rump length & $14.9 \pm 0.13$ & 9.60 & 0.41 & $16.2 \pm 0.23$ & $13.5 \pm 0.12$ & $<.0001$ \\
\hline Rump width & $17.1 \pm 0.18$ & 10.75 & 0.05 & $16.6 \pm 0.31$ & $17.6 \pm 0.17$ & 0.0055 \\
\hline Head length & $16.7 \pm 0.16$ & 10.6 & 0.13 & $17.6 \pm 0.29$ & $15.9 \pm 0.15$ & 0.0001 \\
\hline Head width & $12.4 \pm 0.14$ & 11.84 & 0.06 & $12.81 \pm 0.24$ & $11.9 \pm 0.13$ & 0.0018 \\
\hline Shin circumference & $7.9 \pm 0.07$ & 10.10 & 0.08 & $8.2 \pm 0.13$ & $7.6 \pm 0.07$ & 0.0003 \\
\hline Horn length & $14.8 \pm 0.42$ & 32.04 & 0.11 & $16.5 \pm 0.75$ & $13.1 \pm 0.40$ & 0.0001 \\
\hline Ear length & $14.6 \pm 0.14$ & 10.29 & 0.01 & $14.8 \pm 0.24$ & $14.5 \pm 0.13$ & 0.3341 \\
\hline Cannon bone length & $14.3 \pm 0.11$ & 7.86 & 0.58 & $12.56 \pm 0.84$ & $16.09 \pm 1.35$ & $<.0001$ \\
\hline Testicular circumference & $23.3 \pm 0.23$ & 10.69 & 0.10 & $24.3 \pm 0.41$ & $22.4 \pm 0.23$ & $<.0001$ \\
\hline
\end{tabular}

Values with $(\mathrm{P}<0.05)$ are significantly different from each other. $\mathrm{CV}=$ Coefficient of variation

Table 3. Quantitative body measurements of female goats (LSM $\pm \mathrm{SE}$ ) in the studied districts

\begin{tabular}{|c|c|c|c|c|c|c|}
\hline \multirow{2}{*}{ Effect and level } & \multirow{2}{*}{ Overall } & \multirow{2}{*}{$\mathrm{CV}$} & \multirow{2}{*}{$\mathrm{R}^{2}$} & \multicolumn{2}{|c|}{ Districts } & \multirow{2}{*}{ P-value } \\
\hline & & & & Boset & MinjarShenkora & \\
\hline Body length & $58.7 \pm 0.18$ & 7.53 & 0.02 & $59.4 \pm 0.27$ & $58.0 \pm 0.25$ & 0.0002 \\
\hline Bodyweight & $28.0 \pm 0.24$ & 20.52 & 0.01 & $28.4 \pm 0.35$ & $27.5 \pm 0.33$ & 0.0722 \\
\hline Heart girth & $70.8 \pm 0.21$ & 7.19 & 0.01 & $71.3 \pm 0.31$ & $70.3 \pm 0.29$ & 0.0184 \\
\hline Height at wither & $63.4 \pm 0.19$ & 7.31 & 0.01 & $62.8 \pm 0.28$ & $63.9 \pm 0.27$ & 0.0044 \\
\hline Chest depth & $29.8 \pm 0.10$ & 7.74 & 0.23 & $28.5 \pm 0.14$ & $31.1 \pm 0.13$ & $<.0001$ \\
\hline Shoulder width & $14.4 \pm 0.07$ & 11.49 & 0.02 & $14.1 \pm 0.10$ & $14.6 \pm 0.10$ & 0.0016 \\
\hline Rump length & $14.6 \pm 0.05$ & 8.66 & 0.41 & $15.7 \pm 0.08$ & $13.6 \pm 0.07$ & $<.0001$ \\
\hline Rump width & $17.3 \pm 0.07$ & 9.24 & 0.14 & $16.7 \pm 0.10$ & $18.0 \pm 0.09$ & $<.0001$ \\
\hline Head length & $16.2 \pm 0.06$ & 8.82 & 0.10 & $16.7 \pm 0.09$ & $15.8 \pm 0.08$ & $<.0001$ \\
\hline Head width & $11.6 \pm 0.05$ & 9.31 & 0.01 & $11.7 \pm 0.07$ & $11.5 \pm 0.06$ & 0.0284 \\
\hline Shin circumference & $7.5 \pm 0.03$ & 8.51 & 0.07 & $7.7 \pm 0.04$ & $7.4 \pm 0.04$ & $<.0001$ \\
\hline Horn length & $13.7 \pm 0.16$ & 28.09 & 0.09 & $14.87 \pm 3.79$ & $12.46 \pm 3.85$ & $<.0001$ \\
\hline Ear length & $15.0 \pm 0.06$ & 10.13 & 0.04 & $15.3 \pm 0.09$ & $14.7 \pm 0.09$ & $<.0001$ \\
\hline Cannon bone length & $14.0 \pm 0.05$ & 7.92 & 0.72 & $12.2 \pm 0.07$ & $15.8 \pm 0.06$ & $<.0001$ \\
\hline
\end{tabular}

Values with $(\mathrm{P}<0.05)$ are significantly different from each other. $\mathrm{CV}=$ Coefficient of variation

\section{Body measurement variation in female goats}

Except for body weight, all continuous variables showed significant $(\mathrm{P}<0.05)$ difference between the studied districts (Table 3 ). Body length, rump length, head length, ear length, shin circumference, horn length heart girth and head width were significantly higher $(\mathrm{P}<0.05)$ for Boset district, while, height at wither, shoulder width, rump width, Head width and cannon bone length were significantly $(\mathrm{P}<0.05)$ lower. This could be again due to the variation in the farming system, genetic by environment interaction, or the presence of strains within the breed. The mean body weights $(\mathrm{kg})$ were $28.4 \pm 0.35$ with a range of 17 to 45 and $27.5 \pm 0.33$ with a range 15 to 57 in Boset and Minjar Shenkora district respectively. This wider variation in bodyweight can open an opportunity for improvement of live weight and conservation of the breed. The result is similar to the mean body weight of Keffa (28.2), Abergele (28.4) and Hararghe Highland (28.6) goats and higher than from Afar goat (23.7) (ESGPIP, 2009). The overall traitbased coefficient of variation fluctuated from heart girth (7.19) to horn length (28.09). The population effect $\left(\mathrm{R}^{2}\right)$ ranged from 0.01 for most traits including, body weight, heart girth, height at wither and head width to 0.72 for cannon bone length. This is again attributed to both population and individual differences.

\section{Bodyweight and linear body measurements}

Pearson's correlation coefficient of quantitative body measurements of both sexes is summarized in Table 4 . There was a positive and significant correlation $(\mathrm{P}<0.05)$ between body weight and all other linear body measurements of both sexes. This indicates the possibility of predicting live bodyweight from other body measurements. Bodyweight was strongly correlated with heart girth $(\mathrm{r}=0.80)$ and body length $(r=0.70)$ in female goats, and with heart girth $(r=0.85)$, chest depth $(r=0.73)$ and body length $(r=0.72)$ in male goats. The result is in line with Hagos et al. (2016) for Begait goat. The association between body weight and heart girth, and chest depth could be due to the relatively large contribution in body weight of those traits which consists of bones, muscles and viscera. A combination of those traits would be a better estimator of live bodyweight. However, for easy application under farmer conditions, it would be good to have a few easily measurable traits. The correlation between linear body measurements and bodyweight was higher in male than female counterparts. This highest association of heart girth with bodyweight than other body measurements is in agreement with other results (Hagan et al., 2012; Zergaw et al., 2016; Muluneh et al., 2016) reported for Ghana, Konso and west Gojam goats, respectively. 
Prediction of body weight from other linear body measurements

The regression analysis of live bodyweight on various continuous linear body measurements of both sexes of the studied districts is presented in Table 5. The result of stepwise multiple regression analysis showed that heart girth was the most determinant of live body weight for Minjar Shenkora female (84\%), Minjar Shenkora male $(60 \%)$, and Boset female (57\%), while shoulder width (51\%) was the most significant in the model for Boset male goats. This may be ascribed to the fact that animals with better thoracic development have a higher weight of some vital organs such as the heart and lungs. In most cases, the more inclusion of other body measurements in the model leads to the more accuracy of the model. However, it could be difficult for easy application under traditional management system where farmers mainly intended to do it by themselves. The findings are similar to the report of Halima et al. (2012) and Hagos et al. (2016) for Ethiopian indigenous goats and Begait goats of western Tigray.

\section{Conclusion}

Goat population raised in the two districts have morphological similarity however there are significant differences in most linear body measurements. The existed variation in most measurement traits is an indicator for further improvement opportunity and conservation work that would be designed in the area. Thus, for the breed sustainability and to utilize the resource sustainably, Community based conservation and improvement through selection should be designed in the area for the breed.

Table 4. Correlation coefficients of quantitative body measurements (values above diagonal are for females, otherwise, for males)

\begin{tabular}{|c|c|c|c|c|c|c|c|c|c|c|c|c|c|c|}
\hline Trait & BW & BL & $\mathrm{Hg}$ & HW & $\mathrm{ChD}$ & $\mathrm{W}$ & RL & RW & $\mathrm{HeL}$ & HeW & ShC & $\mathrm{HL}$ & EL & 5 \\
\hline$\overline{B W}$ & & $0.70^{*}$ & $0.80^{*}$ & $0.58^{*}$ & $0.63^{*}$ & $0.38^{*}$ & $0.44 *$ & $0.47 *$ & $0.50 *$ & $0.43^{*}$ & $0.57 *$ & $0.55^{*}$ & $0.19^{*}$ & $0.14 *$ \\
\hline BL & $0.72 *$ & & $0.61 *$ & $0.47 *$ & $0.45^{*}$ & $0.27 *$ & $0.36^{*}$ & $0.31 *$ & $0.37 *$ & $0.32 *$ & $0.42 *$ & $.41 *$ & $0.13^{*}$ & $0.016^{\mathrm{ns}}$ \\
\hline $\mathrm{Hg}$ & $0.85^{*}$ & $0.66^{*}$ & & $0.51 *$ & $0.63^{*}$ & $3 *$ & $.44 *$ & $0.44 *$ & $0.48^{*}$ & $0.40^{*}$ & $0.55^{*}$ & $0.47^{*}$ & $0.17 *$ & $12 *$ \\
\hline HW & $6^{*}$ & 0. & $0.66^{*}$ & & $0.55^{*}$ & * & $0.18 *$ & * & $0.37 *$ & F & s" & $1 *$ & 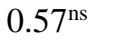 & $31^{*}$ \\
\hline $\mathrm{ChD}$ & $73 *$ & $3 *$ & $0.71^{*}$ & $0.61 *$ & & $0.45^{*}$ & $0.02^{\text {ns }}$ & $0.61 *$ & $0.25^{*}$ & $0.33^{*}$ & $0.29 *$ & $0.28 *$ & $0.05^{\mathrm{ns}}$ & $0.60 *$ \\
\hline W & $061 *$ & $41 *$ & $0.59^{*}$ & $0.50^{*}$ & $0.54^{*}$ & & $0.14^{*}$ & $0.53^{*}$ & $0.28^{*}$ & $0.24 *$ & $39 *$ & $.19 *$ & $-0.05^{\mathrm{ns}}$ & $.33^{*}$ \\
\hline RL & 0 & $0.60 *$ & 0. & 0. & 0.2 & $0.39 *$ & & 0. & $0.52 *$ & $0.28^{*}$ & 5* & $0.44^{*}$ & $0.17 *$ & $-0.41 *$ \\
\hline W & 9* & $0.42 *$ & 0.6 & 4. & $0.64 *$ & $0.62 *$ & $0.20^{*}$ & & $0.25 *$ & $0.22 *$ & $0.29 *$ & $.16^{*}$ & $-0.02^{\mathrm{ns}}$ & $0.56^{*}$ \\
\hline $\mathrm{HeL}$ & $0.55^{*}$ & $51^{*}$ & $0.52 *$ & $0.46^{*}$ & $0.37 *$ & $0.40^{*}$ & $0.62 *$ & $0.32 *$ & & $0.40^{*}$ & $0.50^{*}$ & $.53 *$ & $0.20 *$ & $-0.06^{\mathrm{ns}}$ \\
\hline $\mathrm{HeW}$ & * & $24 *$ & 0. & $0.36^{*}$ & 0. & t* & $0.28^{*}$ & $0.12^{\mathrm{ns}}$ & $0.33^{*}$ & & $0.46^{*}$ & $*$ & 08* & $11 *$ \\
\hline & & & & & & & & & $0.55^{*}$ & $0.46^{*}$ & & ).45* & & \\
\hline HL & $7 *$ & $53 *$ & 0.6 & 0. & 0.4 & $0.39 *$ & $0.51^{*}$ & $0.34^{*}$ & $0.64 *$ & $0.50^{*}$ & $0.59^{*}$ & & $0.19 *$ & $-0.12 *$ \\
\hline EL & $0.18^{*}$ & $0.29^{*}$ & $0.12^{\mathrm{ns}}$ & $0.06^{\mathrm{ns}}$ & $0.20^{*}$ & $0.05^{\mathrm{ns}}$ & $0.15^{\mathrm{ns}}$ & $0.08^{\mathrm{ns}}$ & $0.06^{\mathrm{ns}}$ & $0.08^{\mathrm{ns}}$ & $0.03^{\mathrm{ns}}$ & $0.11^{\mathrm{ns}}$ & & $0.17 *$ \\
\hline $\mathrm{Cl}$ & $16^{*}$ & $-0.05^{\mathrm{ns}}$ & $0.25^{*}$ & $0.35^{*}$ & $0.53^{*}$ & $0.38^{*}$ & $-0.31 *$ & $0.47^{*}$ & $0.01^{\mathrm{ns}}$ & $0.01^{\mathrm{ns}}$ & $0.17^{*}$ & $0.04^{\mathrm{ns}}$ & $0.16^{*}$ & \\
\hline$S C$ & & & & 2 & & $0.18^{*}$ & $0.33^{*}$ & $0.09^{\text {ns }}$ & $0.28 *$ & $0.15^{\mathrm{ns}}$ & $0.28 *$ & $0.34 *$ & $-0.05^{\mathrm{ns}}$ & 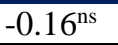 \\
\hline
\end{tabular}

$\mathrm{BL}=$ Body length, $\mathrm{BW}=$ Body weight $\mathrm{Hg}=$ Heart girth, $\mathrm{HW}=$ Height at wither, $\mathrm{ChD}=$ Chest depth, $\mathrm{SW}=$ Shoulder width, $\mathrm{RL}=\mathrm{Rump}$ length, $\mathrm{RW}=\mathrm{Rump}$ width, $\mathrm{HeL}=\mathrm{Head}$ length, $\mathrm{HeW}=\mathrm{Head}$ width, $\mathrm{ShC}=$ Shin circumference $\mathrm{Hl}=$ Horn length, EL=Ear length, $\mathrm{CL}=\mathrm{Cannon}$ bone length, TC=Testicular circumference

Table 5. The regression analysis of live body weight from other LBMs

\begin{tabular}{|c|c|c|c|c|c|c|c|c|c|c|}
\hline \multirow{2}{*}{ Sex } & \multirow{2}{*}{ Equation } & \multirow{2}{*}{$\begin{array}{c}\text { Intercept } \\
\mathrm{A}\end{array}$} & \multicolumn{6}{|c|}{ Regression coefficients } & \multirow{2}{*}{$\mathrm{R}^{2}$} & \multirow{2}{*}{ Error term } \\
\hline & & & $\beta 1$ & B2 & B3 & B4 & B5 & B6 & & \\
\hline \multicolumn{11}{|c|}{ Boset } \\
\hline \multirow{3}{*}{ Male } & SW & -6.83 & 2.66 & & & & & & 0.51 & 4.23 \\
\hline & $\mathrm{SW}+\mathrm{Hl}$ & -6.39 & 2.25 & 0.31 & & & & & 0.66 & 3.60 \\
\hline & $\mathrm{SW}+\mathrm{Hl}+\mathrm{ChD}$ & -19.64 & 1.52 & 0.27 & 0.83 & & & & 0.75 & 3.19 \\
\hline \multirow{6}{*}{ Female } & $\mathrm{Hg}$ & -27.47 & 0.78 & & & & & & 0.57 & 3.20 \\
\hline & $\mathrm{Hg}+\mathrm{BL}$ & -39.13 & 0.60 & 0.42 & & & & & 0.66 & 2.86 \\
\hline & $\mathrm{Hg}+\mathrm{BL}+\mathrm{HeL}$ & -45.80 & 0.56 & 0.40 & 0.66 & & & & 0.68 & 2.78 \\
\hline & $\mathrm{Hg}+\mathrm{BL}+\mathrm{HeL}+\mathrm{ChD}$ & -46.44 & 0.48 & 0.36 & 0.58 & 0.34 & & & 0.69 & 2.73 \\
\hline & $\mathrm{Hg}+\mathrm{BL}+\mathrm{HeL}+\mathrm{ChD}+\mathrm{EL}$ & -47.66 & 0.47 & 0.36 & 0.55 & 0.34 & 0.15 & & 0.70 & 2.70 \\
\hline & $\mathrm{Hg}+\mathrm{BL}+\mathrm{HeL}+\mathrm{ChD}+\mathrm{EL}+\mathrm{RL}$ & -50.04 & 0.46 & 0.35 & 0.49 & 0.31 & 0.16 & 0.33 & 0.71 & 2.67 \\
\hline \multicolumn{11}{|c|}{ Minjar Shenkora } \\
\hline \multirow{2}{*}{ Male } & $\mathrm{Hg}$ & -39.28 & 0.95 & & & & & & 0.84 & 2.31 \\
\hline & $\mathrm{Hg}+\mathrm{BL}$ & -42.75 & 0.80 & 0.25 & & & & & 0.85 & 2.22 \\
\hline \multirow{6}{*}{ Female } & $\mathrm{Hg}$ & -38.91 & 0.25 & & & & & & 0.60 & 4.49 \\
\hline & $\mathrm{Hg}+\mathrm{BL}$ & -37.73 & 1.00 & -0.08 & & & & & 0.63 & 4.48 \\
\hline & $\mathrm{Hg}+\mathrm{BL}+\mathrm{Hl}$ & -29.83 & 0.86 & -0.15 & 0.46 & & & & 0.65 & 4.19 \\
\hline & $\mathrm{Hg}+\mathrm{BL}+\mathrm{Hl}+\mathrm{ChD}$ & -35.50 & 0.49 & -0.20 & 0.33 & 1.18 & & & 0.67 & 3.96 \\
\hline & $\mathrm{Hg}+\mathrm{BL}+\mathrm{Hl}+\mathrm{ChD}+\mathrm{SC}$ & -38.23 & 0.45 & -0.21 & 0.49 & 1.12 & 1.12 & & 0.67 & 3.92 \\
\hline & $\mathrm{Hg}+\mathrm{BL}+\mathrm{Hl}+\mathrm{ChD}+\mathrm{SC}+\mathrm{Sw}$ & -38.18 & 0.41 & -0.20 & 0.29 & 1.08 & 0.87 & 0.36 & & 3.90 \\
\hline
\end{tabular}




\section{Acknowledgements}

This study is financed by Ethiopian Biodiversity Institute. The developmental agents of each district were participated in data collection. The author acknowledges Tadesse Hunduma for his work to map the study area.

\section{Conflict of interest}

\section{No conflict of interest}

\section{References}

Alemu A. 2015. On-farm phenotypic characterization and performance evaluation of Abergelle and Central highland goat breeds as an input for designing a community-based breeding program. MSc Thesis, School of Animal and Range Science, Haramaya University, Haramaya, Ethiopia.

CSA, 2018. Central Statistical Agency. Agricultural sample survey of 2017/2018 (2010 E.C). volume II. Report on livestock and livestock characteristics (private peasant holdings), CSA, Addis Ababa, Ethiopia

Dereje B. 2015. On-farm phenotypic characterization of indigenous cattle and their production systems in Bako tibe and Gobu sayo districts of Oromia region, Ethiopia. MSc Thesis, School of Animal and Range Science, Haramaya University, Haramaya, Ethiopia.

EBI, 2014. Ethiopian Biodiversity Institute. Government of the Federal Democratic Republic of Ethiopia. Ethiopia's Fifth National Report to the Convention on Biological Diversity: Ethiopian Biodiversity Institute, Addis Ababa, Ethiopia.

ESGPIP, 2009. Ethiopia Sheep and Goat Productivity Improvement Program. Goat breeds of Ethiopia technical bulletin No.27: A guide for identification and utilization. http://www.esgpip.org

FOA, 2007. Food and Agriculture Organization of the United Nations. Global plan of action for animal genetic resources and the interlaken declaration: Rome, Italy. ISBN 978-92-5105848-0.

FAO, 2012. Food and Agriculture Organization of the United Nations. Phenotypic characterization of animal genetic resources. FAO Animal Production and Health Guidelines No. 11: Rome. ISBN 978-92-5-107199-1.

Galal S. 2005. Biodiversity in goats. Small Ruminant Research, 60(12): 75-81. https://doi.org/10.1016/j.smallrumres.2005.06.021.

Gatew H, Hassen H, Kebede K, Haile A, Nonato R, Lôbo B, Yetayew A, Rischkowsky B. 2015. Characterization of Indigenous Goat Populations in Selected Areas of Ethiopia. International Center for Agricultural Research in the Dry Areas (ICARDA), 10: 287-298. doi: 10.5829/idosi.aejsr. 2015.10.5.1157
Hagan JK, Apori SO, Bosompem M, Ankobea G, Mawuli A. 2012. Morphological characteristics of Indigenous Goats in the Coastal Savannah and Forest Eco-Zones of Ghana. journal of Animal Science Advances, 2(10): 813-821. www.grjournals.com

Hagos G, Kebede K, Banerjee AK, Wolde Z. 2016. On-Farm Phenotypic Characterization of Begait Goat and Their Production System in Western Zone of Tigray, Ethiopia. International Journal of Research and Innovations in Earth Science, 3: 2394-1375.

Halima H, Michael B, Barbara R, MarkosT.2012. Phenotypic characterization of Ethiopian indigenous goat populations. A frican. Journal of Biotechnology, 11(73):13838-13846. DOI: 10.5897/AJB12.2092

Hansen PJ. 1990. Effects of coat colour on physiological responses to solar radiation in Holsteins. Vet Rec, 127(13):333-4. PMID: 2256242.

Ia ML, Haoa SZ, Ianb CB, Anga HW, Eid HW, Iua L, Ua MY, Ana BF, Hena SC, Hua, MZ, Ia SL, Ionga TX, Ia KL. 2002. Genetic relationships among twelve Chinese indigenous goat populations based on microsatellite analysis. Genetics selection evolution, 34(6):729-44. DOI: 10.1186/1297-968634-6-729

Khargharia G, Kadirvel G, Kumar S, Doley S, Bharti PK, Das M.,2015. Principal component analysis of morphological traits of Assam hill goat in Eastern Himalayan India. Journal of Animal \& Plant Sciences, 25(5): 1251-1258.

Mahmoudi B, Bayat M, Sadeghi R, Abdollahi H. 2010. Genetic Diversity among Three Goat Populations Assessed by Microsatellite DNA Markers in Iran Laboratory of Veterinary Science. Faculty of Specialized Veterinary Science, 4: 118124.

Muluneh B, Kebede K, Mekasha Y, Science R, Campus DT. 2016. Phenotypic Characterization of Indigenous Goat Types in West Gojam Zone, Amhara National Regional State, Ethiopia. Journal of Biology, Agriculture and Healthcare, 6: 54-64. https://www.iiste.org/Journals/index.php/JBAH/article/ view/29506/30296

Tesfalem A, Abebe H, Abraham A, Tesfaye G, Manaye M, Seble S, Fasil G, Solomon A. (2021). Goat breeding practice and production constraints in Boset and Minjar Shenkora districts of Ethiopia. Genetics and Biodiversity Journal, 5(2) : 107-115

Zergaw N, DessieT, Kebede K, Ababa A, Dawa D. 2016. Goat production Constraints and Ethno-veterinary practices in Konso and Meta-Robi districts; Ethiopia. International Journal of Research and Reviews in Pharmacy and Applied Sciences, 6: 1308-1317. http://ijrrpas.com/article/goatproduction-constraints-and-ethno-veterinary-practiceskonso-and-meta-robi-districts 